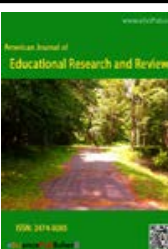

American Journal of Educational Research and Reviews

(ISSN:2474-9265)

\title{
Teachers' Perception of Guidance Counsellors' Task Performance in Secondary Schools in Anambra State
}

\section{EGENTI UJU. P. (Ph.D)}

Department of Educational Foundations, Faculty of Education, Chukwuemeka Odumegwu Ojukwu University, Igbariam Campus, Anambra State, Nigeria (Formerly Anambra State University, ULI)

\section{ABSTRACT}

This study investigated teachers' perception of guidance counselors' task performance in secondary schools in Anambra State. Four research questions guided the study. Three hypotheses were tested at 0.05 level of significance. Descriptive survey research design was adopted for the study. The population comprised 6,857 teachers from 257 public secondary schools in Anambra State. A sample of 685 was drawn using proportionate stratified random sampling techniques. Data was collected using a questionnaire of 30 items developed by the researcher and titled 'Teachers' Perception of Guidance Counsellors Task Performance Questionnaire" (TPCTPQ) which was validated by experts. Internal consistency reliability index of 0.82 was obtained for the entire instrument using Cronbach's alpha. Data analysis was done using mean and standard deviation for the research questions, while t-test was used to test the hypotheses. The finding reveals among others that Teachers' Perception towards guidance counsellors Task Performance is high. Male and female teachers' perception towards guidance counsellors' tasks performance is high. Teachers in urban and rural areas perceive guidance counsellors' tasks performance as being high. The study also found that teachers in urban and rural areas did not differ significantly in their perception of guidance counsellors' task performance. Based on the findings of the study it was recommended among others that there is need to have professionally trained school counselors for effective delivery of guidance and counseling services in the schools. There is also need for sufficient facilities and finances for effective delivery of guidance and counseling tasks.

Keywords: Teachers' Perception, Guidance Counsellors' Task Performance, Secondary Schools, Anambra State

${ }^{*}$ Correspondence to Author: EGENTI UJU. P. (Ph.D)

Department of Educational Foundations, Faculty of Education, Chukwuemeka Odumegwu Ojukwu University, Igbariam Campus, Anambra State, Nigeria (Formerly Anambra State University, ULI)

How to cite this article:

EGENTI UJU. P. Teachers' Perception of Guidance Counsellors' Task Performance in Secondary Schools in Anambra State. American Journal of Educational Research and Reviews, 2018,3:20.

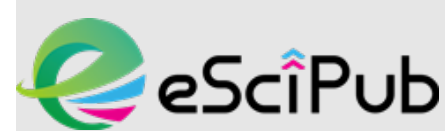

eSciPub LLC, Houston, TX USA. Website: http://escipub.com/ 


\section{Introduction}

Guidance and counselling is an integral part of educational system. It provides guidance programmes for secondary school students to address the physical, emotional, social, vocational and academic difficulties of adolescent students. This is to complement learning in the classroom and also enhance academic performance and achievements of students. Guidance plays a vital role in preventing educational, personal, social, mental and other similar problems among secondary school students.

Guidance and counselling can be seen as a programme of activities which provides us with the gateway out of numerous problems in our present age of complex scientific and technological development (Okobiah \& Okorodudu, 2014). Okobia and Okorodudu further noted that guidance is a programme of services to individuals based on their needs and the influence of environment factors. Guidance and counseling is a professional field which has a broad range of activities, programmes and services geared toward assisting individuals to understand themselves, their problems, their school environment and the world and also to develop adequate capacity for making wise choices and decisions.

The goal of guidance and counseling services is to enable learners in institutions to learning derive optimal educational benefits so as to actualize their potentialities. Egbochukwu (2018) asserted that the aims of school guidance and counseling services are to provide students opportunities to develop knowledge and appreciation of themselves and others, to develop relationship skills, ethical standards and a sense of responsibility.

According to Akinade (2016), the major functions of guidance and counseling services is to provide opportunities for each student to reach his full potentials in the areas of education, vocational, personal, and emotional development. In line with this, Paul (2016) affairs that guidance and counseling services prepare students to assume increasing responsibility for their decision and grow in their ability to understand and accept the result of their choices.

Educational services are the advice given to learners to help them make suitable decisions regarding their education (Bulus, 2017). According to Phillips (2017), counseling, assists students in applying effective study skills, setting goals, learning effectively, and gaining test-taking skills. Counselors also may focus on note taking, time management, memory techniques, relaxation techniques, overcoming test anxiety, and developing listening skills (Kahinde, 2011). Educational guidance services have essential role to play in making sure that students' educational decisions are grounded in sound decision and students are helped to develop effective self-management in education and career oath. Denga (2011), asserted that educationally, guidance and counseling services' role is to help the students adapt to school, make educational decisions and choice by informing them about educational facilities. These educational services according to Eremie (2014) help students to choose the most appropriate electives courses and students club for their interests and abilities and help them more effectively by introducing them to effective study method.

Socio-personal services are those services that are designed to assist the students to understand and accept himself thereby clarifying his ideas, perception, attitudes, and goals; furnishes personal and environmental information to the students, as required, regarding his plans, choices, or problems; and seeks to develop in the student the ability to cope with/ and solve problems and increased competence in making decisions and plans for the future (Marchetta, 2011). Guidance counsellors are expected to do personal and crises counselling. Socio-personal services is concerned with the developmental needs of the 
individual in personal and social areas such as developing awareness about interpersonal relationships beginning from the early ages; working on communication skills, life skills social skills, problem-solving skills, decisionmaking skills; working on anger management, dealing with peer pressure and developing healthy relationships with opposite sex (Bulus,2017). Socio-personally, guidance and counseling services help the recipients to know and understand themselves, accept their superiors and limited features and develop effective interpersonal relationships, become a personally and socially balanced and harmonious individuals (Bojuwoye, 2017). Thus, they enable the continuous developing individuals to manage the developmental tasks at various developmental stages.

Vocational services according to Kehinde (2011) are the process of assisting the individual to choose an occupation, prepare for it, and enter upon it and progress in it. It is concerned primarily with helping individuals make decisions and choices involved in planning a future and building a career. The purpose behind assisting the youths to choose, prepare, enter and progress in vocation is the optimum growth of the individual. According to Denga (2011), vocational services are those services and activities intended to assist individuals of any age and at any point throughout their lives, to training and occupational choices and to manage their careers. Nwachukwu (2017) defined vocational services as those activities within schools that help students clarify career goals and understand the world of work; personal or group-based assistance with decision about initial courses of study, courses of vocational training, further education and training, initial job change, or work-force re-entry; computerbased or on-line services to provide information about jobs and careers or to help individual make career choices; and services to produce and disseminate information about jobs, courses of study and vocational training.
Vocational services refer to service that assist individual to make wise educational occupation choice and to manage their career (Field \& Boesser, 2017).

Notwithstanding the importance of guidance and counseling services, it appears that these services are not encouraged and performed at the secondary school level. Apart from academic problems of failure and dropout of students from schools, other numerous psychosocio; vocational and personal-socio problems abound among students in secondary schools. Parents and other stakeholders in the education sector in recent times have been concerned about these academic problems of students. It is of importance that guidance counselors carryout personal, social, educational and vocational guidance in order to attend to students' educational, vocational, emotional and social development, bearing in mind their developmental needs and problems (Denga, 2011).

Guidance and counselors are to offer a sufficient level of services in educational, vocational, personal and social areas; services affecting the students directly such as appraisal, psychological counseling, information gathering and outreach, orientation and placement, follow-up, orientation; and services affecting the students indirectly such as consultation, research and evaluation, and public and family relations. Teachers' perception regarding counsellors' performance these task areas remains unknown. It is based on this therefore, that the study determined teachers' perception of guidance counsellors' task performance in secondary schools in Anambra State.

The Federal Republic of Nigeria (FRN,2013) laid emphasis on the importance of guidance and counseling programme in secondary schools. Despite this emphasis, its effectiveness in ensuring discipline and academic performance appears not to have been achieved. The stakeholders in public secondary schools in Anambra State especially 
teachers have continued to question the effectiveness of guidance counselors in their task performance.

Some teachers hold mis-concepts about the role and task of counselors because they are often misinterpreted as administrative assistants who have little time to spend counseling students. Fueling the conception is the fact that some teachers mistrust counselors, due to their apparent alignment with administration. Teachers who are uncooperative and unsupportive have criticized developmental guidance in general. These teachers believe that counselors play little or no emphasis on student behaviour or students performance. They do not like students from their classroom working with counselors. They may even refuse to send their students to the guidance office. Their refusal to send students to counselors is based on the belief that counselors appear not to perform their tasks effectively, and sending students to the guidance office is a waste of time that only penalizes the students. Although, other teachers send their students to see the counselors, but only during break time (Anwuana, 2014). It is based on these misconceptions that the researcher investigated teachers' perception of guidance counsellors' task performance in secondary schools in Anambra State.

\section{Research Questions}

Four research questions guided the study.

1. What is the perception of teachers toward guidance counsellors' task performance in Anambra state?

2. What is the perception of male and female teachers toward the task of guidance counsellors in Anambra state?

3. What is the perception of teachers in urban and rural areas towards the task performance of guidance counsellors in Anambra state?

4. What is the perception of experienced and inexperienced teachers towards the task performance of guidance counsellors in Anambra State?

\section{Hypotheses}

The following null hypotheses were tested at 0.5 level of significance.

1. There is no significant difference in the mean rating of male and female teachers' perception of guidance counsellors' task performance in Anambra State.

2. There is no significant difference in the mean ratings of teachers in the urban and rural in their perception of guidance counsellors' task performance in Anambra State.

3. There is no significant difference in the mean ratings of experienced and inexperienced teachers in their perception of guidance counsellors' task performance in Anambra State.

\section{Research Method}

The design adopted in the study is descriptive survey research design. It was carried out in secondary schools in Anambra state. The population of the study comprised 6,857 teachers in 257 public secondary schools in the state. The sample size for the study consisted of 685 teachers drawn from the population of the study. The sample consists of $10 \%$ of the entire population. The proportionate stratified random sampling technique was used to draw the sample size. The instrument for data collection was a structured questionnaire titled "Teachers Perception of Counsellors' Task Performance Questionnaire" (TPCTPQ) designed by the researcher. The instrument consisted of two sections: A and B. Section A elicited information on the demographic information on the counsellors' task performance in secondary schools. The section $B$ part of the instrument was rated on 4-point rating scale of Strongly Agreed (SA), Agreed (A), Disagreed (D) and Strongly Disagree (SD) weighted as $4,3,2$, and 1 respectively. The validity of the instrument was established by two experts comprising one in Guidance and 
Counselling and one in Measurement and Evaluation, all in Faculty of Education, Nnamdi Azikiwe University, Awka.

The reliability of the instrument was established by administering 20 copies of the instrument on a representative sample of 20 teachers randomly selected from 5 public secondary schools in Enugu State. The scores obtained from the respondents were collated to determine the internal consistency of the scores for the items in each section. This was done using Cronbach Alpha that yielded reliability coefficient of $0.82,0.78$ and 0.87 for the 3 sections respectively.

The researcher administered the instrument to the respondents with the help of three research assistants who were properly briefed and trained for the study. This enabled them be familiar with the modalities for administering the instrument in an appropriate and effective way. The researcher and the assistants administered copies of the instrument on the teachers at their various schools using direct administration and retrieval method. Mean and standard deviation were used to answer the research questions. In analyzing the data, mean from $1.00-1.49=$ very low; $1.50-2.49=$ low; $2.50-3.49=$ high; $3.50-4.00=$ very high. In analyzing the data for the null hypotheses, t-test was used to test the hypotheses 0.05 level of significance. As a rule, if the calculated $\mathrm{t}$-value is equal or greater than the table t-value (.05), the null hypotheses was rejected whereas if the calculated t-value is less than the table t-value, the null hypotheses was not rejected.

\section{Presentation of Results}

The results are presented according to the research questions and hypotheses.

\section{Research Questions}

Research Question1: what is the perception of teachers toward guidance counsellors' tasks performance?

Table 1: Mean score of teachers on guidance counsellors' tasks performance

\begin{tabular}{llrrl}
\hline & $\mathrm{N}$ & Mean & SD & Remark \\
\hline Counsellors' task performance & 681 & 2.91 & 55 & High \\
\hline
\end{tabular}

The mean score of 2.91 shown in Table 1 above indicates that teachers' perception towards guidance counsellors' task performance is high.
Research Question 2: what is the perception of male and female teachers towards guidance counsellors' task performance?

Table 2: mean score of male and female teachers on guidance counsellors' task performance

\begin{tabular}{lcccc}
\hline & $\mathrm{N}$ & Mean & SD & Remark \\
\hline Male & 282 & 2.93 & .44 & High \\
Female & 399 & 2.90 & .61 & High \\
\hline
\end{tabular}

The mean score of 2.93 for males and 2.90 for females in Table 2 shows that male and female teachers' perception towards guidance counsellors' tasks performance is high.
Research Question 3: what is the perception of teachers in urban and rural areas towards guidance counsellors' task performance? 
Table 3: mean score of teachers in urban and rural areas on guidance counsellors' task performance

\begin{tabular}{lcccc}
\hline & N & Mean & SD & Remark \\
\hline Urban & 526 & 2.90 & .56 & High \\
Rural & 155 & 2.96 & .50 & High \\
\hline
\end{tabular}

The mean score of 2.90 and 2.96 for teachers in urban and rural areas indicates that teachers' in urban and rural areas perceive guidance counsellors' tasks performance to be high.
Research Question 4: what is the perception of experienced and inexperienced teachers towards guidance counsellors' task performance?

Table 4: mean score of experienced and inexperienced teachers towards guidance counsellors' task performance

\begin{tabular}{lcccc}
\hline & N & Mean & SD & Remark \\
\hline experienced & 532 & 2.90 & .54 & High \\
inexperience & 149 & 2.94 & .55 & High \\
\hline
\end{tabular}

Table 4, shows the mean scores of 2.90 and 2.94 for experienced and inexperienced teachers. Both mean scores indicated that experienced and inexperienced teachers perceptive guidance counsellors' tasks performance to be high.

\section{Hypotheses}

Hypothesis One: Male and female teachers do not differ significantly in their perception of guidance counsellors' task performance.

Table 5: t-test comparison of male and female teachers' mean score on guidance counsellors' task performance

\begin{tabular}{lccccccc}
\hline Source of Variation & $\mathrm{N}$ & \multicolumn{1}{c}{ Mean } & SD & $\mathrm{df}$ & $\mathrm{t}$-cal & $\mathrm{t}$-crit & Decision \\
\hline Male & 282 & 2.93 & .44 & & & & \\
& & & & 697 & .90 & 1.96 & Not sig \\
Female & 399 & 2.90 & .61 & & & & \\
\hline
\end{tabular}

The result in Table 5 shows that the calculated t-value (.90) is less than the critical value (1.69) at alpha level of 0.05 and degree of degree of freedom (df) 697 . This is an indication that the difference in the perception of male and female teachers on guidance and counsellors' tasks performance was not significant. The null hypotheses therefore were not rejected.
Hypothesis Two: teachers in urban and rural areas do not differ significantly in their perception of guidance counsellors' task performance.

As indicated in Table 6, the analysis shows that the $t$-cal value of 1.17 is less than the critical value of 1.96 at alpha level of 0.05 and degree of freedom (df) 679. This shows that urban and rural teachers do not differ significantly in their http://escipub.com/american-journal-of-educational-research-and-reviews/ 
perception of guidance counsellors' task in the perception of experienced and performance. inexperienced teachers on guidance and

The result in Table 7 shows that the calculated t-value (.65) is less than the critical value (1.96) at alpha level of 0.05 and degree of freedom counsellors' tasks performance was not significant. The null hypotheses therefore were not rejected.

(df) 679. This is an indication that the difference

Table 6: t-test comparison of urban and rural teachers' mean score on guidance counsellors' task performance

\begin{tabular}{lrrrrrrr}
\hline Source of Variation & $\mathrm{N}$ & Mean & SD & df & t-cal & t-crit & Decision \\
\hline Urban & 526 & 2.90 & .56 & & & & \\
& & & & 679 & 1.17 & 1.96 & Not sig \\
Rural & 155 & 2.96 & .50 & & & & \\
\hline
\end{tabular}

Table 7: t-test comparison of experienced and inexperienced teachers' mean scores on guidance counsellors' task performance

\begin{tabular}{lccccccc}
\hline Source of Variation & $\mathrm{N}$ & Mean & $\mathrm{SD}$ & $\mathrm{df}$ & $\mathrm{t}$-cal & $\mathrm{t}$-crit & Decision \\
\hline Experienced & 532 & 2.90 & .54 & & & & \\
inexperienced & 149 & 2.94 & .55 & & & & \\
\hline
\end{tabular}

\section{Summary of the Findings}

From the analysis presented in this study, the major findings are as follows:

1. Teachers' perception towards guidance counsellors' task performance is high.

2. Male and female teachers' perception towards guidance counsellors' task performance is high.

3. Teachers in urban and rural areas perceive guidance counsellors' task performance to be high.

4. Experienced and inexperienced teachers have a high perception regarding guidance counsellors' task performance.

5. Male and female teachers did not differ significantly in their perception of guidance counsellors' task performance.

6. Teachers in urban and rural areas did not differ significantly in their perception of guidance counsellors' task performance.
7. Experienced and inexperienced teachers do not differ significantly in their perception of counsellors' task performance.

\section{Discussion of Findings}

The findings of the study as indicated in Table 1 shows that teachers' have a high perception towards guidance counsellors' tasks performance in secondary schools in Anambra state. The finding of this study is in line with the finding of Eremie (2014), who in his study found that teachers perceive that counsellors guide students towards their vocational guidance needs. The findings of this study also supports that Akinde (2016) who in his study about teachers perception of guidance and counseling services found that teachers have a positive perception about counseling services provided by guidance counsellors in secondary schools. This finding is also consistent with that 
of Beesley and Frey (2014). Their study revealed that principals reported overall satisfaction with counseling services provided by counsellors in secondary schools. These findings are in line with Kehinde (2011) who indicated in his study that teachers have a positive perception regarding the roles performed by counsellors.

This study found that male and female teachers have a high perception towards guidance counsellors' tasks performance in secondary schools in Anambra State. This findings supports that of Eremie (2014), who found that male and female teachers perceived that counsellors to adequately guide students to resolve their personal-socio problems. The finding also revealed that male and female teachers perceived counsellors to guide students towards their vocational guidance needs. The findings also in conformity with Skutley (2006) wherein they stated that notwithstanding the misconceptions about guidance counsellors' tasks in secondary schools, teachers still have a positive high perception regarding counsellors' perception. The finding of the hypothesis indicates that there is no significant difference in the perception of male and female teachers on guidance and counsellors' task performance. Earlier study by Eremie (2014) also found no significant differences in male and female teachers' perception of the role of guidance counsellors in secondary schools.

The finding in Table 3, shows that teachers in urban and rural areas perceive guidance counsellors; task performance to be high. The findings of the study did not agree with that of Bojuwoye (2017) who found that urban teachers rated guidance counsellors' task performance higher than their counterpart in the rural area. According to him, the situation in the village secondary schools is not encouraging, the awareness is very poor and the activities of the few guidance and counseling units are so limited due to lack of equipment and financial aid. To a reasonable extent, majority of teachers in rural secondary schools feel that the programme is only for students with physical problems, hence little patronage from most students. Geographical location is one of the strong determinants of guidance and counseling services in schools. Teachers in urban schools are predisposed to guidance and counseling services than those in rural schools. It could be argued that teachers in the urban schools must have had more awareness of the guidance and counselling task performance. Moreover, almost all the schools in the towns are equipped with counseling units and school counsellors as compared to rural secondary schools which some of them may not have counsellors in the schools. The finding of the hypothesis indicates that the difference in the perception of teachers in urban and rural areas on guidance counsellors' tasks performance was not significant. The reason for this may be because teachers in the rural areas are beginning to be conscious of guidance and counsellors' task performance in the rural schools as it is the situation in urban schools.

Table 4 shows that experienced and inexperienced teachers perceive guidance counsellors' tasks performance to be high. This finding is not in congruence with that of Marchetta (2011) who found that participants who had more than 10 years of experience, were more likely to have a high perception of counsellors' role. The finding of the hypothesis showed that experienced and inexperienced teachers did not differ significantly in their perception of counsellors' task performance. This contrary to the findings of Marchetta (2011) who found that there are significant gaps in older and younger generation teacher perceptions pertaining counsellors roles and responsibilities.

\section{Conclusion}

From the data interpretation and discussion of results from findings of this study, the following conclusions were drawn. Teachers' perception towards guidance counsellors' task performance is high. Male and female teachers' 
perception towards guidance counsellors' task performance is high. Teachers in urban and rural areas perceive guidance counsellors' task performance to be high. Experienced and inexperienced teachers have a high perception regarding guidance counsellors' task performance.

Male and female teachers did not differ significantly in their perception of guidance counsellors' task performance. Teachers in urban and rural areas did not differ significantly in their perception of guidance counsellors' task performance. Experienced and inexperienced teachers do not differ significantly in their perception of counsellors' task performance.

\section{Recommendations}

Based on the findings of the study, the following recommendations were made:

1. There is need to have professionally trained school counsellors for effective delivery of guidance and counselling services in the schools.

2. Principals should relief guidance counsellors' heavy teaching loads so as to allow them to practice effectively.

3. There is need for sufficient facilities and finances for effective delivery of guidance and counselling tasks.

4. The Government of Anambra State should endeavour to establish counselling units in each secondary school, and should be functional to meet the needs of counsellors.

\section{References}

1. Akinade, E.A. (2016). Introduction to modern guidance and counselling. Ibadan:Bright ways publishers.

2. Anwuana, U.I. (2014). An analysis of occupational preferences of farm five students in secondary schools in Cross River State. Education 3 (1) 31 - 38

3. Beesley, D. \& Frey, L. L. (2014). Principals' perceptions of school counsellors roles and satisfaction with school counselling services. MSC project. University of Oklahoma, USA.

4. Bojuwoye, J.O. (2017). Analysis and appraisal of current guidance services in Kaduna State secondary schools. An unpublished M.Ed.
Thesis. Faculty of Education, Ahmadu Bello University, Zaria.

5. Bulus, I. (2017). Guidance practice in schools. Jos Ehindero Nig. Ltd.

6. Denga, D.I. (2011). Eduactional and vocational guidance in Nigeria secondary schools. Jos: Savana Press Ltd.

7. Egbochukwu, E. O (2018). Assessment of the quality of guidance and counselling services to students' adjustment in secondary schools in Edo State of Nigeria. Research Journal of International Studies 8, 81 - 90

8. Eremie, D. M (2014). Teachers' perception of the roles of guidance counsellors in secondary schools in Rivers state. Journal of Business and Management Review 4(3), 98 - 103.

9. Federal Republic of Nigeria (FRN, 2013). National policy on education. Lagos: NEDRC Press.

10. Fields, M., \& Boesser, C. (2017). Constructive guidance and discipline: Preschool and primary education. Upper Saddle River, NJ: PrenticeHall, Inc.

11. Kehinde, A. (2011). Perceived best practices of school counsellor in Local Education Districts of Lagos State. Annual National Conference of the Counselling Association of Nigeria (CASSON).

12. Marchetta,J.M. (2011). Teacher perceptions of the school counsellors' role. The College at Brockport, State University of New York.

13. Nwachukwu, D. N. (2017). Guidance and counselling practicum. $\left(2^{\text {nd }}\right.$ ed) Calabar: University of Calabar Press.

14. Okobiah, O.C., \& Okorodudu, F. R. (2014). Perception and multiple roles of the school counsellor and his ethical Code of Conduct. Paper presented at the Orientation Course for Teacher-Counsellor at Nsukka Secondary School.

15. Paul, V. B (2016). Journal of in-service education: the school principals' role in teacher professional development. Retrieved from http://www.tandfonline.com/doi/pdf/10.1080/1367 4580000200114.

16. Philips, J.A. (2017). Manager-Administrator or Instructional Leader: Shift Role of the Principal. From

"http://www.learningdomain.com/principallnstruct Leader. Htm (Retrieved March 14, 2017)

17. Skutley, K. E. (2006). Teacher perceptions of the role of a school counsellor. Master of Science Degree in Guidance and Counselling, The Graduate School, University of Wisconsin-Stout.

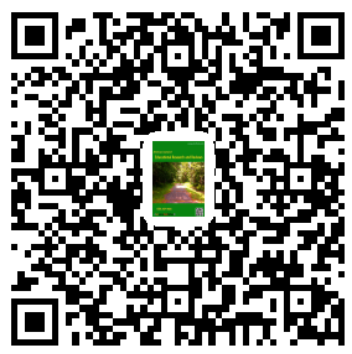

